\title{
THE STRUCTURING OF SÃO PAULO CITY FROM THE ROADS AND RAILS (1867-1930)
}

\section{A estruturação da cidade de São Paulo a partir dos caminhos e trilhos (1867- 1930)}

\author{
lara Sakitani Kako ${ }^{1}$ \\ Jorge Pimentel Cintra ${ }^{1}$ \\ ${ }^{1}$ Universidade de São Paulo-USP - Escola Politécnica - Departamento de Engenharia de Transportes \\ Av. Prof. Almeida Prado, Travessa 2, no. 83 Edificio Engenharia Civil.Cidade Universitária - São Paulo - \\ Brasil - CEP.: 05508-070.
}

Emails: iarakako@usp.br; ipcintra@usp.br

\begin{abstract}
:
This article presents a proposal for using digital cartography applied to the comparative analysis of a series of 13 historical maps of São Paulo city. The analysis sought to establish links between the rail transport infrastructure and the process of structuring the city of São Paulo between 1870 and 1930. Therefore, we produced thematic maps from a selection of historical maps of the city and the following were identified: urban sprawl, existing neighborhoods, planned housing developments, paths design, railways and streetcars. It proved to be a practical way for digital cartography to be supported by Geographic Information Systems made more agile for handling, visualization and overlapping information in different historical maps, facilitating the comparative analysis process of the structuring role of paths and trails in the formation of the urban area, the work hypothesis verified at the end of the article.
\end{abstract}

Keywords: Roads, Rails, São Paulo, Cartography, Historical-maps, Geographic Information Systems.

\section{Resumo:}

O presente artigo apresenta uma proposta do uso da Cartografia digital para a análise comparativa de mapas históricos, com eixos temáticos orientativos, utilizando como objeto de estudo 13 mapas antigos da cidade de São Paulo. Nessa proposta procurou se, como foco de análise, estabelecer relações entre a infraestrutura de transporte por trilhos e o processo de crescimento e estruturação da cidade de São Paulo no período de 1870 a 1930. Para tanto foram produzidos mapas temáticos a partir dos mapas selecionados e neles foram identificados os 
seguintes elementos: mancha urbana, bairros existentes, loteamentos planejados, traçado de caminhos, ferrovias, tramways e bondes. Comprovou-se de forma prática, que a Cartografia digital apoiada nos Sistemas de Informações Geográficas torna mais ágil a manipulação, a visualização e a sobreposição das informações contidas nos diferentes mapas históricos, facilitando o processo comparativo de análise do papel estruturante dos caminhos e trilhos na formação da malha urbana, hipótese de trabalho que se verificou ao final da pesquisa.

Palavras-chave: Caminhos, Trilhos, São Paulo, Cartografia, Mapas-históricos, Sistemas de Informação Geográfica.

\section{Introduction}

This article is primarily concerned with assessing the impact of roads and rails on the structuring of the layout of the streets of São Paulo performing a comparative analysis of maps produced between the late nineteenth century and the early twentieth century (1870-1930). The spatial area of this study is the expanded center of São Paulo, starting the analysis from its old center (first historical streets of the city), in the course of the analysis, different neighborhoods aggregated at different times were added. This addition occurred having as an axis the old paths and, particularly, those constituted by the rails.

The 1870s, as highlighted by (Villaça, 2009), was considered a turning point in the growth of urban and intra-urban space in Brazil. That decade is marked by the explosive growth of the city of São Paulo, with the beginning of the operation of the São Paulo Railway, established in 1867. According to the author, the inauguration of this railway accentuated the division of the city expansion space creating a barrier, beyond those already existing, such as rivers and their floodplains, making it difficult to access the East zone.

The urban maps of São Paulo in that period reveal a city in full transformation and development, visible by the expansion of its boundaries, in parallel with the infrastructure works, such as railways and streetcars, water distribution systems, gas and electricity, along with the allotments of chácaras (small farms), the opening of streets, avenues and squares. The economic, industrial and population growth, due to birth and particularly to immigration, led to the emergence of new neighborhoods, integrating isolated peripheries and the occupation of floodplains. This growth has always been conditioned by its genesis; but linked to the chaotic growth, there are structural elements and our work hypothesis was that it corresponds to the railway leading role.

Regarding the modernity of São Paulo, (Santos, 1994) states: “The story of a city is produced by the urban space it incorporates or does not incorporate; the urban space that elsewhere may be delayed, and that in São Paulo always came almost immediately." In our review, this incorporation is analyzed in comparison with the development of rail transport, starting from a series of maps selected to represent the period and that have been studied, mostly by (Cintra, 2004) and (Campos, 2008). 


\section{Materials and Methods}

Among the various ways of understanding the maps, one is sure to see them as a tool for knowledge, planning and analysis; if applied to an urban issue, it has social and political components and consequences (Harley, 2005).

Therefore, with due caution, we did not hesitate in using historical maps as a source of information for research on the geographic space, its transformations and the society of their time. Interpreting them correctly becomes a challenge for those who are concerned with using them as a documentary source.

Both natural objects such as hydrography and relief were studied, as well as the rails, which are considered geographical objects integrating the territorial configuration of the city, as in (Santos, 1996).

For the analysis of the maps selected, the (Monbeig, 1957) proposal to study the process of evolution of cities was favored; it states:

The most perfect way to ensure the success of this part of the urban monography is to gather a reasonable number of city plans from different times, choosing the most representative, for example, those separated by time intervals neither too short nor too long, in those dates that were critical to the city's past and finally to analyze these plans.

This citation represents a whole work program. From it, we opted for selecting a set of maps that would enable to assess the expansion of the city. Thus, for this study, in which the dominant factor was the implementation and extension of the railways, a periodicity was chosen; a priori, the 10-year order, except the first map that corresponds to pre-train phase of São Paulo. Then, we verified the existence of maps with that span in time and their availability.

After the pre-selection according to these criteria, the choice of the most significant maps was made because they contained information on streetcar lines, railways and tramways (small steam locomotives), and also so that the set was a sequential sample to be able to characterize the evolution of the urban space in Sao Paulo. The complete list of maps used as a reference lies at the end of the article, being of the following years: 1847, 1850, 1868, 1877, 1881, 1890, 1897, 1905, 1914, 1924 and 1927.

To study the paths and tracks of the city in the late nineteenth century, which changed little in the period under study, we used the map by Carlos Abraham Bresser "Plan of the City of São Paulo" form 1847.

The analyses presented herein were based on the methodology proposed in (Cintra, 2012), which allowed preparing thematic maps from the information extracted from the sequence of historical maps, as well as overlaying this information, generating useful cartographic products. The digital mapping technique used is also described in (Machado, 2010) and allows comparing maps with different scales and geographic projections.

Describing the procedure, in general lines, after obtaining the maps in digital format, they were recorded by using a Geographic Information software. As a basis of comparison (and adjustment), an updated map of São Paulo in vector format was employed, in this case, the Digital City Map (MDC, 2005), the most recent mapping available. 


\section{Results and Discussion}

The results, presented in the form of maps, seek to illustrate and to visually support the process of expansion of the urban sprawl of Sao Paulo, with maps of this period, also showing the growth of the network of tracks and their influence on the process.

Figure 1 shows the 1847 map, depicting the city ways leading inland and towards the coast. The layout is the result of the superposition of four layers of information.

The preparation of the cartographic product began with the main layer, that is, the 1847 map used as a base in raster format, recorded with common points of that map and the current map (MDC, 2005), from which the coordinates of these common points were drawn.

The second layer consists of the layout of paths (see the maps in Figure 1) defined based on the description of the colonial paths made by the architect and urban planner (Reis, 2004). As is known, Sao Paulo was the area of confluence of paths that, from the coast, led to the inland of the captaincy and of the continent in general.

The third and fourth layers are composed of the main hydrography, drawn from the information of the very map itself, as well as the bridges represented by brown triangles. When looking at the map, the urbanized area of the city is verified to correspond to its initial core between Anhangabaú and Tamanduateí, rivers extending along the roadside; i.e. the paths directing the occupation.

Thus, the map in Figure 1 accomplishes its representation and positioning functions, combining the historical map information produced in the nineteenth century with the current map of the city of São Paulo, with its current streets (MDC 2005).

This map along with its design and the names allows recognizing the paths drawn from the end of the urbanized area as a bold brown line. These paths are written as follows:

1. Way to Mooka [sic], to the east (which went to Penha and to Rio de Janeiro)

2. Way to Santos, southwards (to the coast)

3. Way to Sorocaba recorded westwads on the map, the extension of Consolação Street.

4. The Way to Minas Gerais and Goiás was also drawn, but there is no written reference on the map.

The map shows four bridges over the River Tamanduateí: Tabatinguera, Carmo, Ferrão and Do Meio. Over the Anhangabaú, spelled "R. Nanhabaú "[sic] are the bridges of Constituição, Lorena and an unnamed bridge, next to the seminary. The Santa Anna Bridge appears on a stretch of the Tiete River, in the upper left corner of the map (not present in Figure 1).

Bridges and paths guided and determined not only the movement of people and goods, but also the establishment of new streets and housing developments.

The plan mainly follows the topography (spike, ravines border, etc.) and somehow the hydrography (valley); the streets have an irregular route at the beginning, which was settled even in the early centuries of occupation, by aligning the buildings, giving rise to the Direita (right) streets: Direita de São Bento, Direita de Santo Antônio, Direita da Misericórdia and others. Later, as from the nineteenth century, with the expansion to the so-called Centro Novo, the urban design turned hypodamic with streets crossing at right angles. 
The 1847 urban sprawl was observed to concentrate in the so-called Triângulo (central triangle) of the city, bordered by the Anhangabaú and Tamanduatei rivers, and closed to the south by Tabatinguera Street in the Liberdade neighborhood. In addition to this main spot, there was the current region of Luz which, at the time, had small farms and some isolated buildings: the Casa da Correção (Jail), the Convento da Luz (Monastery), the Hospital dos Lázaros (Leprosarium), in addition to the Jardim Botânico (Botanical Gardens, now Jardim da Luz), constituting an urbanized spot isolated from the core of the city.

In addition, there were Chácaras (small ranches) near the urban area, such as in the current region of Praça da República (Republic Square) named Campo do Curro (Farms of Brigadeiro Luis Antonio, Jose Arouche de Toledo Rendon, and the Prado family) and in the Bras region where were the Chácaras of Bresser and of the Bispo (Bishop), were located on the road to Moóca, crossing the Tamanduateí floodplain.

Another secluded urban spot is the Moóca near the Tabatinguera Bridge on the road leading to Rio de Janeiro.

As known, this growth was due to a number of factors, including the coffee economy, which led to the implementation of the railway, the installation of financial capital and the large influx of immigrants as from the late nineteenth century. This resulted in the creation of factories and workers' districts on the sides of railways, with the consequent demand for infrastructure: potable water, energy, transport, housing and sanitation

The geographic position of crossroad, paths used by troops for transporting goods, towards the coast or inland, marked its role as the capital, as a decision center, a communications node and necessary path to the port of Santos. This determined the implementation of the first railway line in the city in 1867 and later the junction of others. Figure 1 represents the city pre-railway phase. 


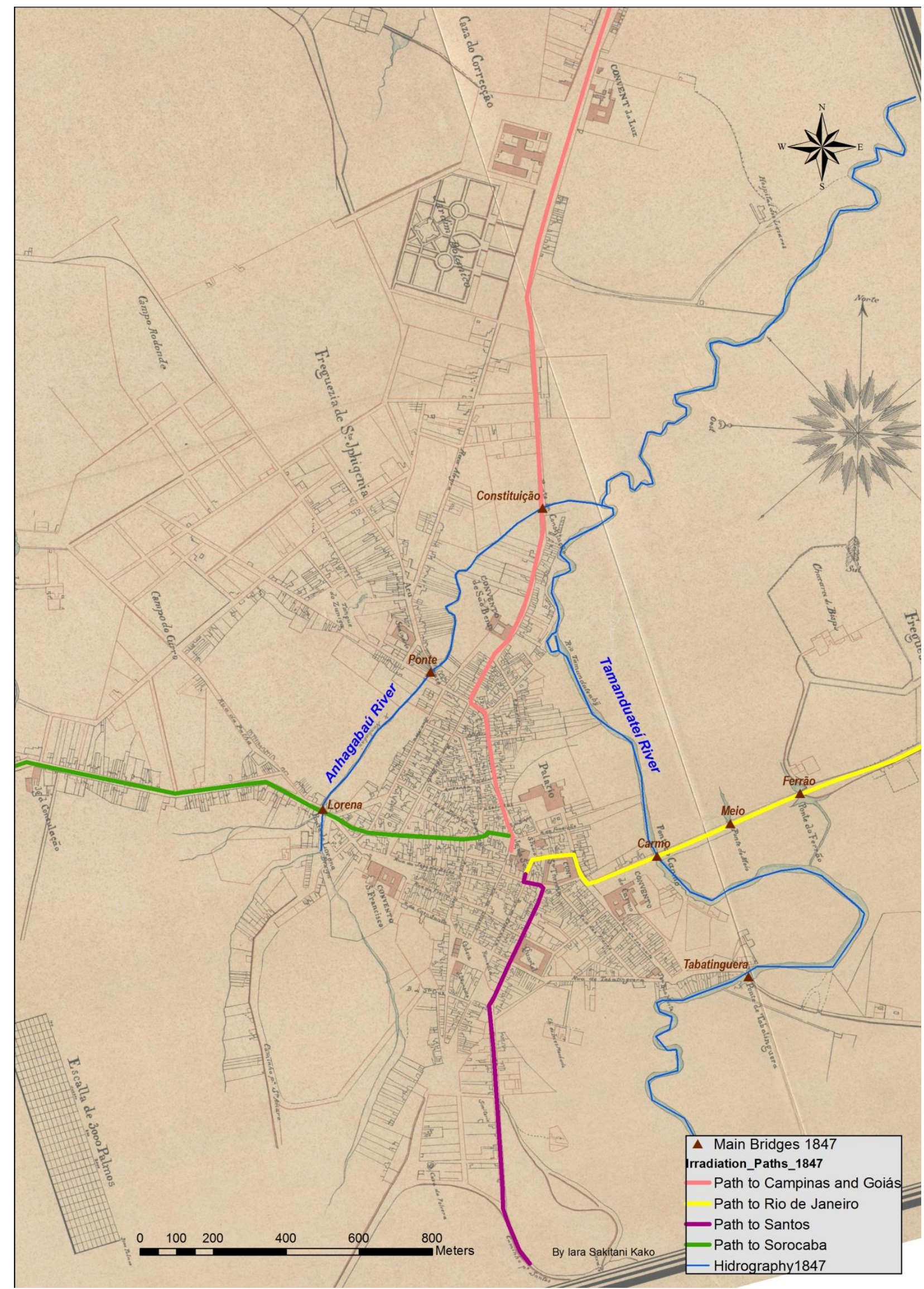

Figure 1: Map of Sao Paulo - irradiation paths (XIX century) 
The concept of periodization has a very valuable role in geography because it allows making space and time empirical together. Thus, values are assigned to objects according to each period. The paths crisscrossing the city, its inns, mule fairs and troops had their due value during the prerail period.

Figure 2 shows an enlarged detail of the map shown in Figure 1, with the addition of the layer containing the current streets (MDC, 2005). In this figure you can see the main buildings, streets and squares, as that of the Cathedral. The overlap of the current streets layer with their names allows comparing the design of the streets and also the places names (toponomy).

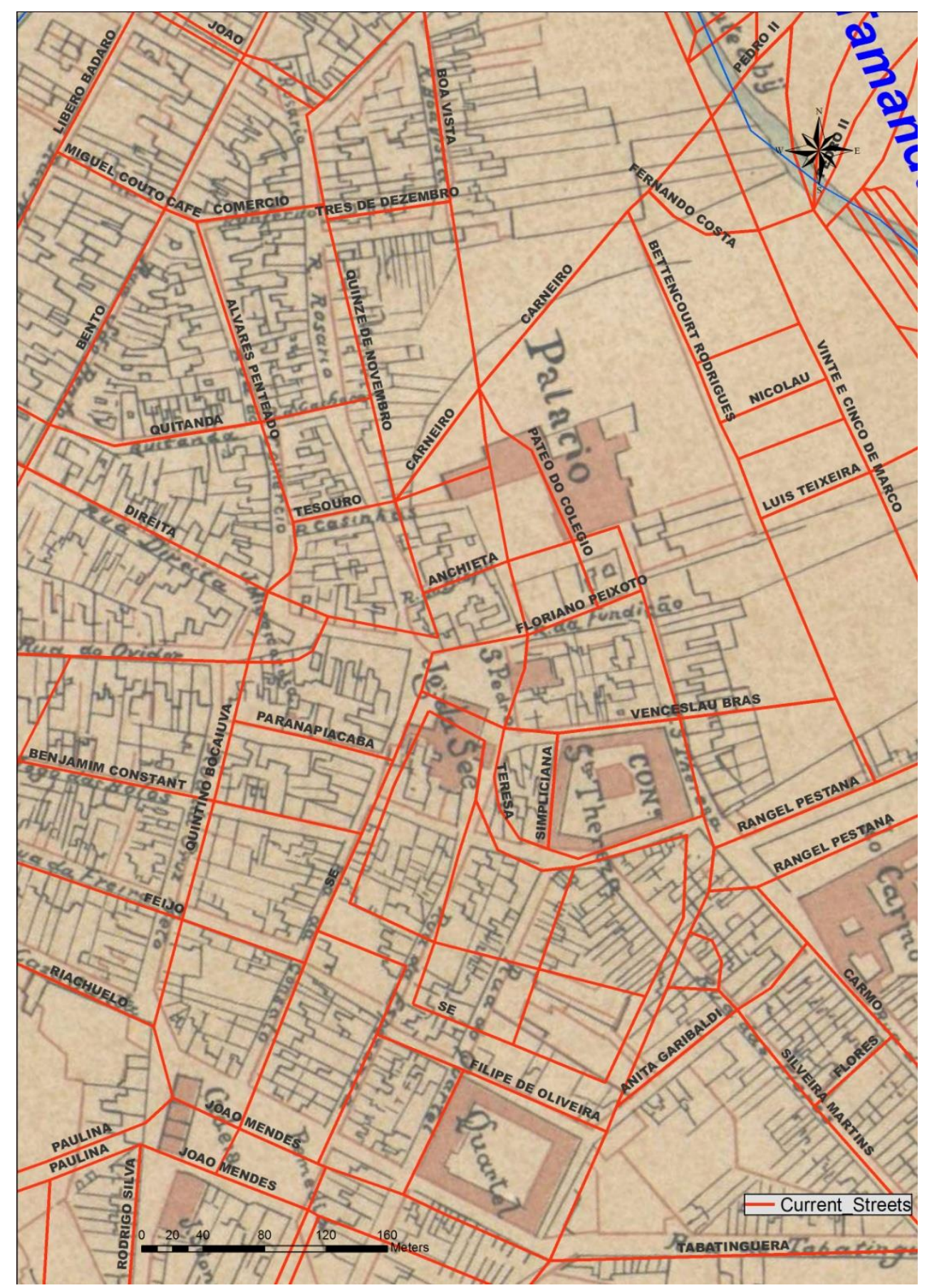

Figure 2: Map of São Paulo (detail) - Outward paths in the XIX century, overlapped by the current streets. 
This figure demonstrates that the map designer drew not only the streets but also the full lots (estates), and may be additionally classified as a simplified registration plan. It is worth noting that the void on the floodplain of the Tamanduatei River would later be occcupied as shown in the layout of the current streets.

Figure 3 shows the result of the superposition of the following layers of information extracted from the historic map from 1905: streetcar lines, factories, urban sprawl and railway stations.

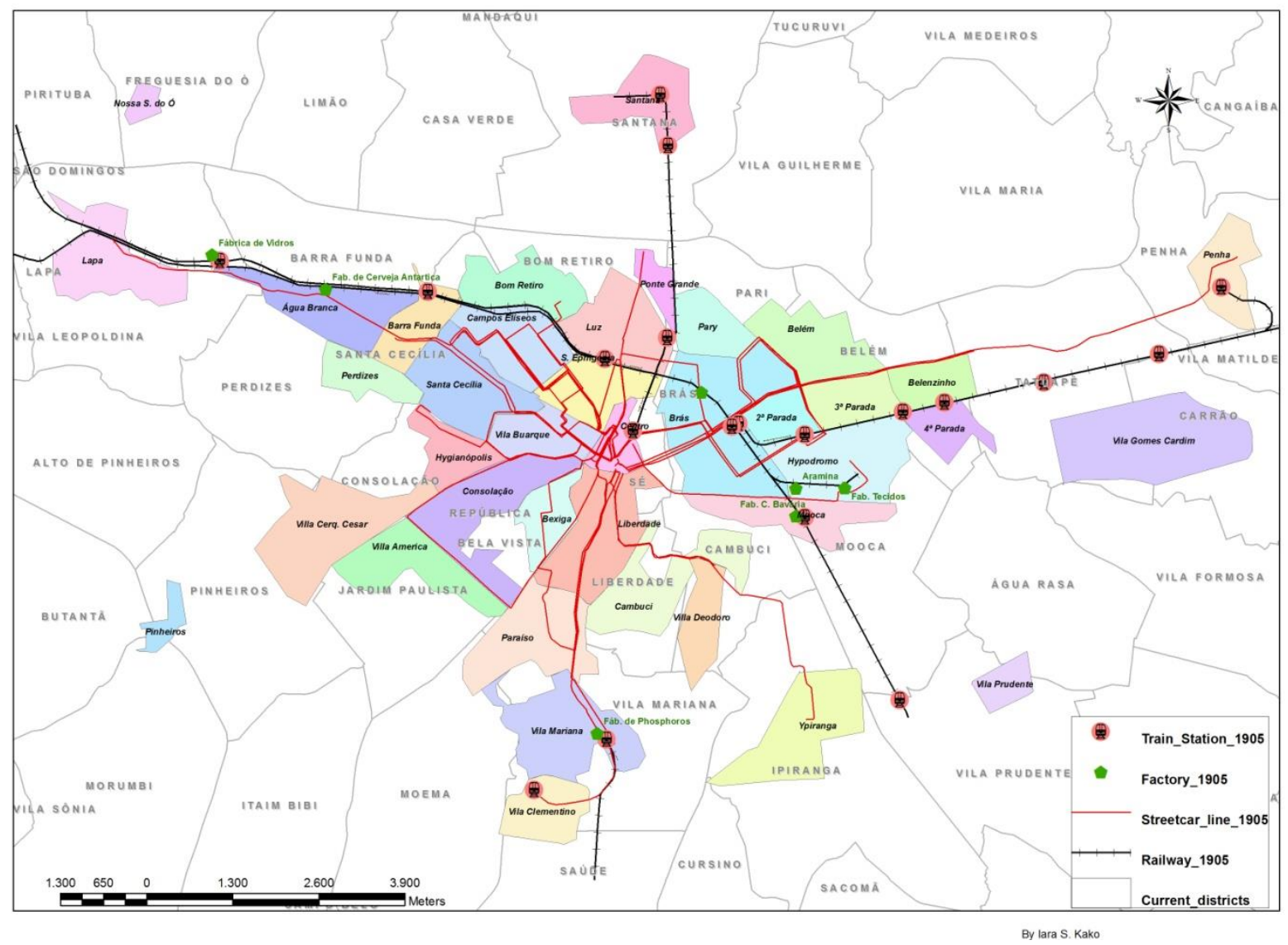

Figure 3: Map of the urban sprawl, the rails and railway stations in São Paulo (1905)

Completing this overlapping action, the layer "districts" represents the districts existing in the city from information extracted from the current map (MDC, 2005). The superposition of the current delimitation of the districts indicates the possibility to correlate current data with those of the past. The preparation of the map was intended to show the relationships among the urban area, rails, train stations and factories.

The rails permeate most of the surface of the urban sprawl, showing the relationship between them and the urban area, with a few exceptions, such as Pinheiros, Freguesia do $O$ and Vila Prudente (isolated neighborhoods), although the latter was partially served by the Ipiranga station of the SPR (Saint Paul Railway, the British Railway). Maps of this type allow studying in detail how the population was served in terms of public transportation between home and work.

The growth of the city of São Paulo in the last decades of the nineteenth century was vertiginous, and many small farms were partitioned in a process of real estate speculation and of the construction of a social stratification that would last decades, as verified in Villaça (2009).

The city occupation partition in this period can still be seen as an east-west division, having as a reference to two major geographic objects: the Tamanduatei River with its floodplains and the 
railway line, following this river and also the Tiete River. Figure 3 shows that the factories along the railroads, especially in the eastern districts and, in the surrounding neighborhoods, the workers' neighborhoods (Belém, Pari, Moóca).

Predominantly residential neighborhoods for the upper and middle class were developed westwards: Campos Elíseos, Higienópolis, Santa Cecilia and Cerqueira César. These western districts were well served by the streetcar lines, while the others only counted on the railroad.

Figures 4, 5 and 6 show the comparison of thematic maps of the years 1905, 1914 and 1924, respectively, in order to relate the growth of the urban expansion with the rails.

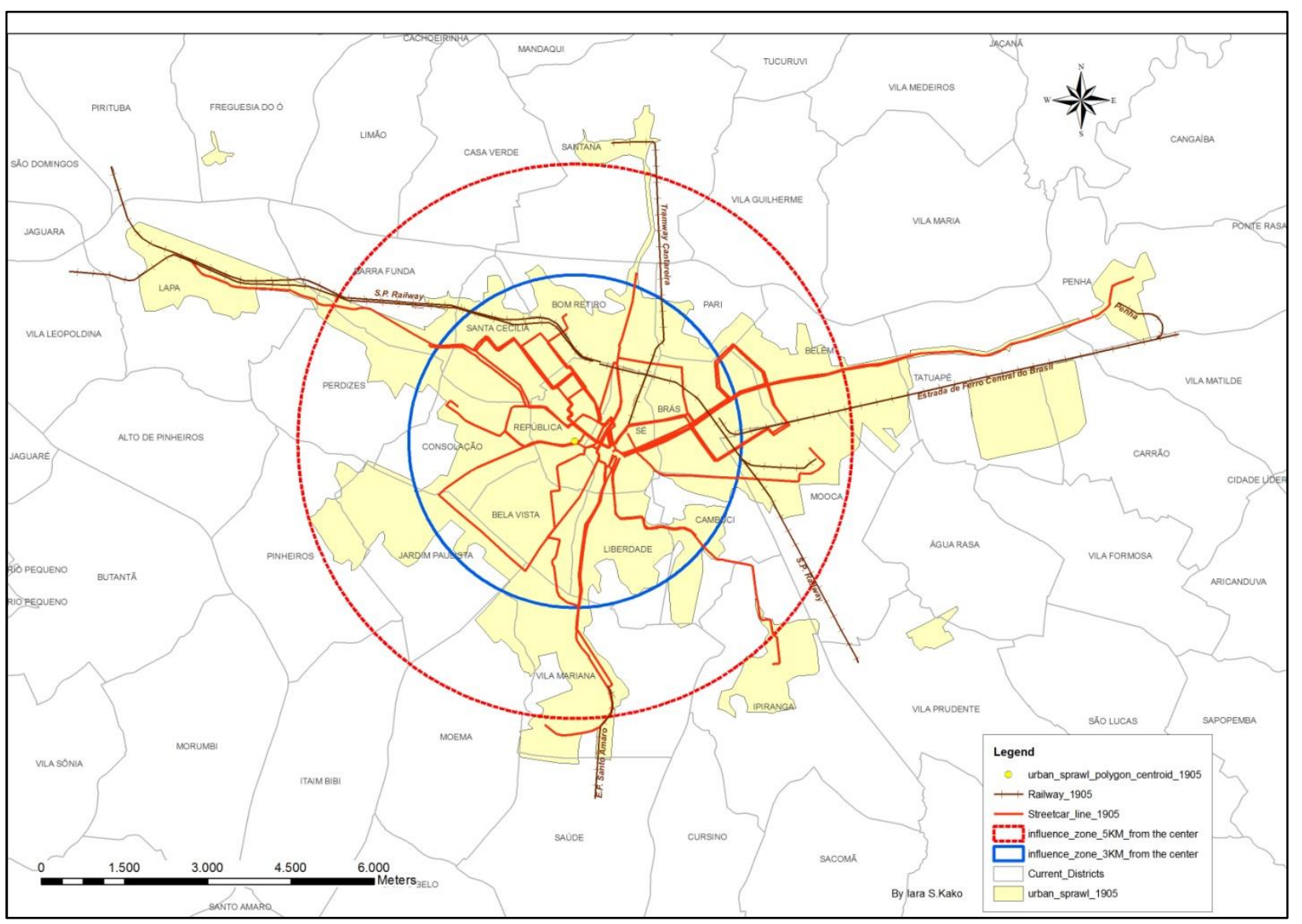

Figure 4: Streetcars lines and the urban sprawl of São Paulo (1905)

Based on the central point of the city located in the historic center (polygon centroid representing the urban area), concentric circles (buffers) were traced with three and five kilometers, respectively, making it easier to visualize and to compare the expansion of the urban spot within the circles (buffers) drawn.

The first circle, with a 3-kilometer radius from the central point of the urban area, was drawn to this dimension to incorporate the entire central area of the city; the second, a five-kilometer radius, to involve the peripheral area of the city.

We thought of two types of displacement within these circles, where up to three kilometers is could be covered on foot. In the central circle, there is an increased number of streetcar lines serving the center; besides an increase in urban sprawl between the two circles drawn, mainly in the west and in the southwest of the city. 
Figures 5 and 6 also show the new called allotment: streets in gray are those that do not appear in previous maps. The map of Figure 6 (1924) shows a dense network of streetcar lines in the first area, the zone of influence of the center. Compared with the map in Figure 5 (1914), an expansion of the streetcar rail network is perceived, and that there was an extension of the rails to reach the neighborhoods of Casa Verde, Sacomã, Indianapolis, Pari and Lapa; two branches were inserted in the Bela Vista line to serve Jardim Paulista.

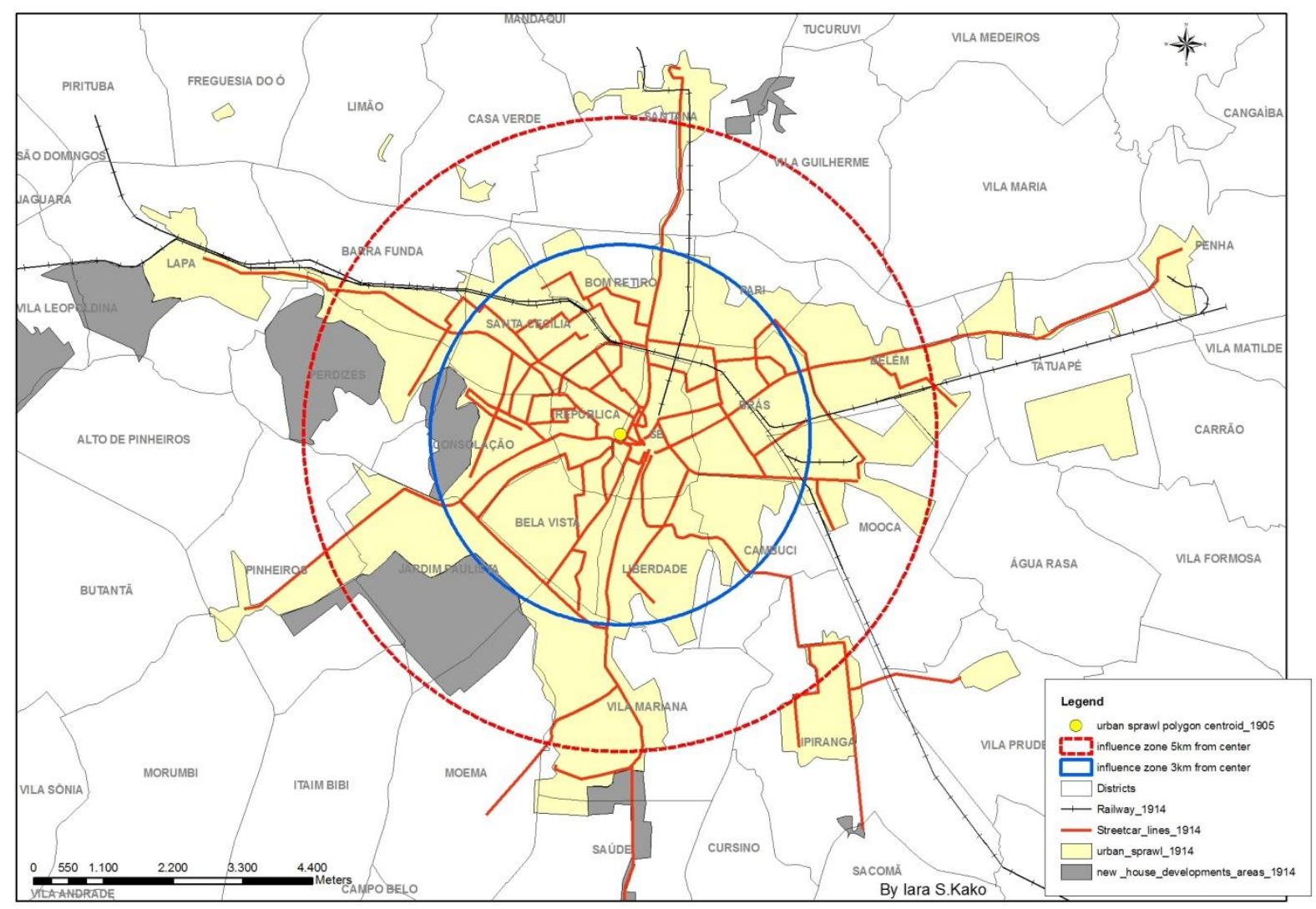

Figure 5: Streetcar lines and urban sprawl in 1914 - São Paulo.

Thus, the inhabited urban area and the rails expanded practically together: sometimes the rail preceded the demand; other times they derived from urbanization, which demands transport.

The first electric streetcar in Sao Paulo dates back to 1900. In 1905, the number of streetcar lines circulating in the city was 21; in 1924, São Paulo had approximately 56 streetcar lines branching off from the center to all the directions of the city (Stiel, 1978).

In Figure 6 (1924) more evidently depicts the city with its rails, also enabling to identify small clusters of neighborhoods forming the north, west and east of the expanded center. To the south, the formation of neighborhoods with large housing developments that most often have the design of the urban road network following a parallelism with the rails, as in the Indianópolis neighborhood, located between the current districts of Moema and Brooklin. 


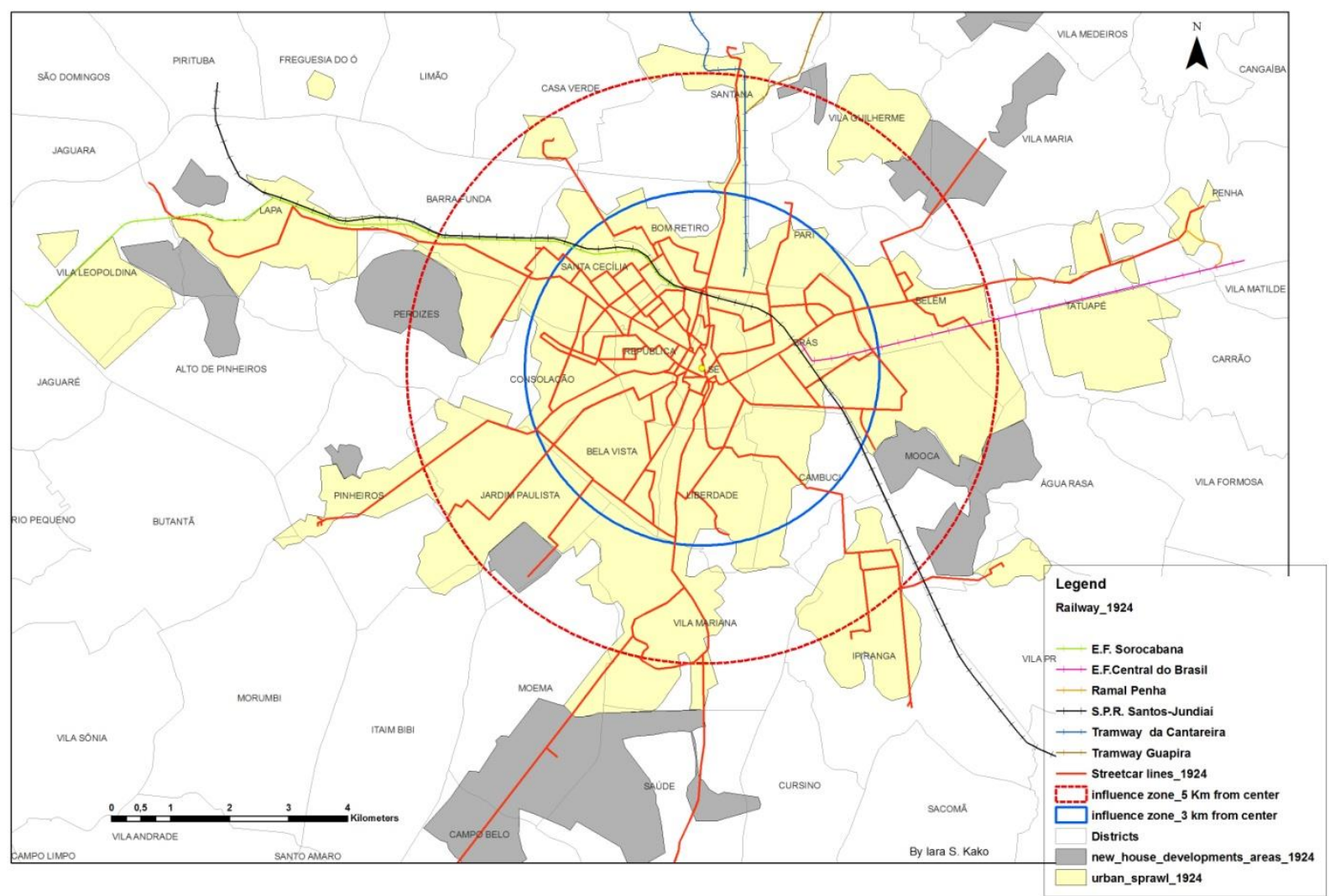

Figure 6: Streetcars lines and urban sprawl in 1924 - São Paulo.

This parallelism determined the direction of the main arteries, of the secondary ones and their crossing in a hypodamic layout of new neighborhoods. A few neighborhoods escape this geometry: Aclimação, designed by Ramos de Azevedo and others planned by the City Company (Jardim America, Jardim Europa, Pacaembu, Lapa and some others). Also differing from that design were sites with a very rugged topography.

As the growth of the urban sprawl in the period selected for this study was quite extensive, to synthesize the results in maps Figure 7 was drawn. This shows an overlay of the layers containing the design of urban sprawl on the different dates and thus combines information from different maps. Due to the complexity and for better visualization, the representation of the urban area growth was divided into two periods. 


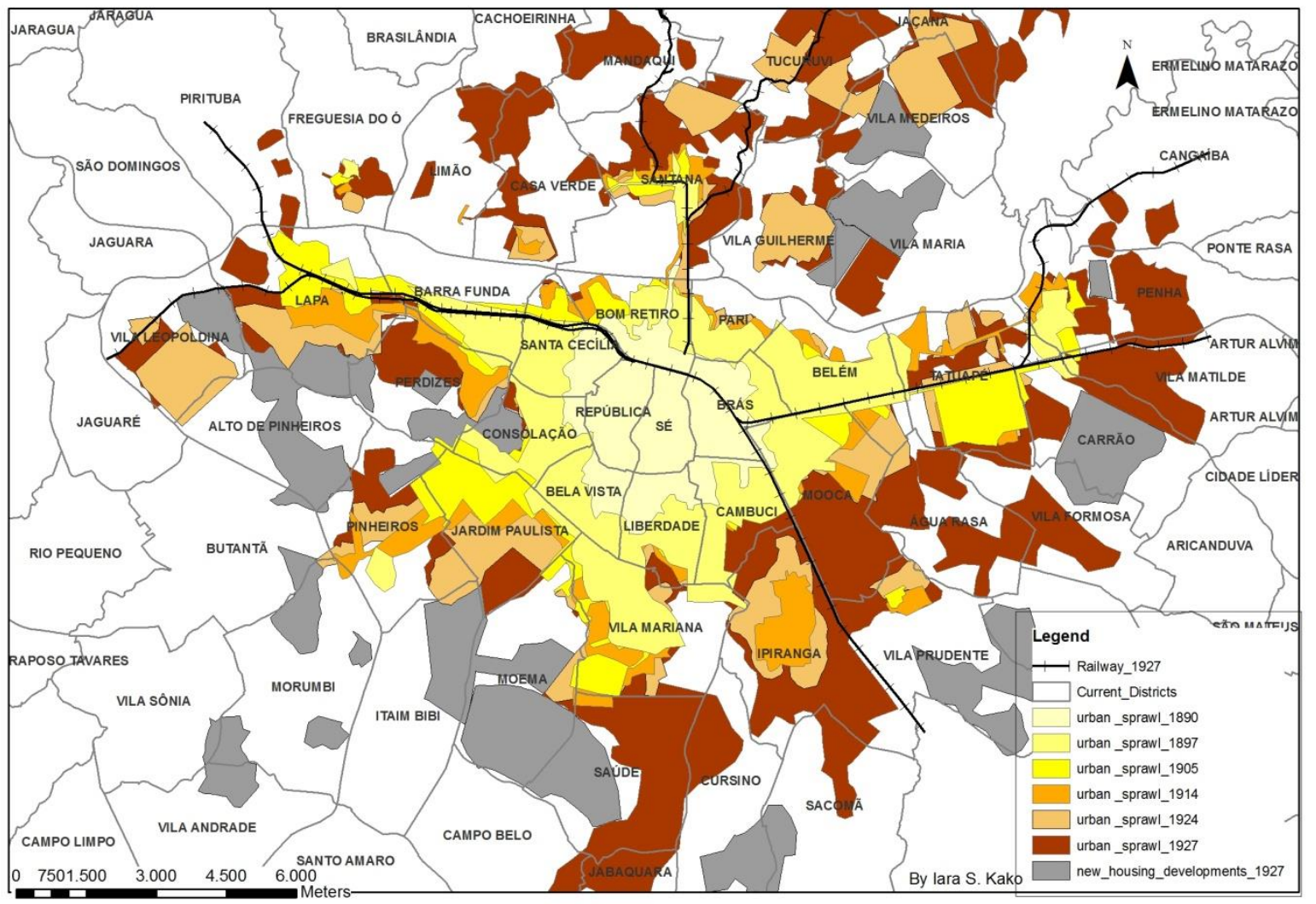

Figure 7: Growth of urban sprawl 1890-1927 - São Paulo.

In the period 1847-1890, the growth of the urban area was confined to the central area of the city with a small extension to Brás (in 1881), and a larger increase in area in 1890 occupying the edges of the railways. This growth, represented in yellow in the figure, was significant considering the period in which it occurred but seems timid when compared to later periods.

The next period spanned from 1890 to 1927 . This includes the 1897 map, which shows the real city as well as the planned one with its expanded boundaries. By overlaying the different maps, the visual result shows a city that doubles in size in the early twentieth century with its multicore discrete neighborhoods as regards the central area. During the process of overlapping layers "blank" spaces on the map were gradually eliminated and the result appears on a map with the central area, as provided by Gomes Cardim in 1897, fully interconnected without voids. In the study by (Simoni, 2009), Gomes Cardim's map is studied in detail.

Neighborhoods such as Ipiranga, Pinheiros, Lapa and Vila Mariana, in the nineteenth century, were considered far from the center due to the lack of a transport link or the time it took to get to them. In the 1920s, they formed a single urban area and were connected the rail mode. Specifically, the Ipiranga neighborhood counted on being close to the railroad Santos-Jundiai and, a little later, it benefited from the implementation of the streetcar way and then the streetcar.

The city grew in a discontinuous fashion, which hindered its planning and the implementation of transport, energy, water and infrastructure in general. It seems that this may be related to the value of the land and its accessibility: very close to downtown sites, the resistance of the owners to selling the small farms, except for a highly profiting price, made land values inaccessible for building affordable housing; on the other hand, sites located far from the means of transport did not invite occupation. 
Therefore, the existence of the railway, the streetcar ways and streetcars led to the establishment of new settlements in the regions served by them. The other elements of urban infrastructure (water, sewer, electricity) either did not exist at any point of the city or were quite restricted, something that made public transportation the main weighting element for defining the occupation of the urban territory.

However, it was not the only one and was associated with others, such as problems related to the poor quality of the land (floodplain, topography). An example is the case of the Pacaembu neighborhood, which had a late occupation, despite having lines of streetcars nearby and being adjacent to other neighborhoods already occupied; this derived from the topography and flooded floodplain of the Pacas stream, the translation of Pacaembu into Tupi, the language of the Indians of Sao Paulo.

There was a strong interaction between the railway and the streetcar service, which initially had among its major functions to interconnect the central districts to the railway stations of $L u z$, Norte and Brás. The railway was located outside or on the edge of the town.

The set railroad, streetcar way and streetcars, showed that the existence of rails was the main factor geographically, also directing the implementation of new housing developments, structuring the city setting at different times.

\section{Conclusions}

From the cartographic analysis, later confirmed by the literature, the role of the rail proved not only to improve the flow of goods, but also to enable the transport of passengers, promoting the formation, expansion and access to new land, guiding the use and type of land use, perceptible from the visualization of the expansion of urban areas and the railway as a whole.

The rails (streetcars, streetcar ways and trains), focus of this research, showed to be some of the main structural elements of the urban space occupation, preceding, in importance and chronologically, the implementation of water systems, sewage and electricity. Other influencing elements, as pointed out, were the paths, closely related to the topography and hydrography (watersheds, wetlands, valley bottoms).

Rail transport was observed to exert strong influence on the planning of the expansion of the urban area linked to the spatial selectivity, called spatial segregation by some authors. Also to be pointed out is their impact on the territorial structure of the city, combined with other elements, which were not the focus of this study and which deserve further studies: public policy planning, real estate speculation, transportation service concessions and later the distribution of power and water.

Some samples of the wider research that led to the present work were presented, (Kako, 2013), allowing proving that the digital cartography, and particularly the comparative map overlay, is a very valuable study technique for geographers, urban planners and other professionals. This was possible at other times, using analog means; this was greatly facilitated by digital mapping and Geographic Information Systems, which provided great flexibility to the process.

Bol. Ciênc. Geod., sec. Artigos, Curitiba, v. 22, no4, p.574 -588, out - dez, 2016. 


\section{REFERENCES}

Campos, Eudes, "A vila de São Paulo do Campo e seus caminhos", Revista do Arquivo Municipal / Departamento do Patrimônio Histórico (2006):11-34.

Campos, Eudes, "São Paulo antigo: plantas da cidade", Informativo do Arquivo Histórico Municipal, 4 (2008): 20, accessed March, 2016, http://www.arquiamigos.org.br/info/info20/iindice.htm.

Cintra, Jorge P., "Digital Cartography and Historical Maps: techniques, applications and peculiarities". Revista Brasileira de Cartografia. Rio de Janeiro 64, n. 6 - p. 901- 918. 2012.

Cintra, Jorge. P, "Plantas Históricas," in São Paulo vista do Alto: 75 anos de aerofotogrametria, ed. Idoeta, Irineu et al. (São Paulo: Érica, 2004), 96.

Comissão do IV Centenário da Cidade, São Paulo antigo plantas da cidade (São Paulo: Melhoramentos, 1954), 11.

Gregory, Ian, and Ell, Paul, Historical GIS: Technologies, Methodologies, and Scholarship (Cambridge: Cambridge University, 2007), Kindle edition.

Harley, Brian, La Nueva Naturaleza de los Mapas (México: Fondo de Cultura Económica, 2005), 398.

Kako, Iara S, "O papel dos trilhos na estruturação territorial da cidade de São Paulo de 1867 a 1930" (PhD Thesis, Universidade de São Paulo, São Paulo, 2013).0,

Matos, Odilon. N., Café e ferrovias: a evolução ferroviária de São Paulo e o desenvolvimento da cultura cafeeira (Campinas: Pontes, 1990), 178.

Monbeig, Pierre, Novos Estudos de Geografia Humana Brasileira (São Paulo: DIFEL, 1957), 238.

Pérez Machado, Reinaldo Paul, " Sobreposição da cartografia digital vetorial às cartas e mapas históricos da Cidade" (paper presente at the $3^{\circ}$ Simpósio Iberoamericano de História da Cartografia, São Paulo, April 26-30, 2010)

Reis Filho, Nestor Goulart. São Paulo: Vila, Cidade, Metrópole (São Paulo: Prefeitura do Município de São Paulo, 2004), 261.

Saes, Flávio Azevedo Marques, As Ferrovias de São Paulo, 1870-1940: expansão e declínio do transporte ferroviário em São Paulo (São Paulo: HUCITEC, 1981), 199.

Santos, Milton, Metamorfoses do Espaço Habitado: Fundamentos Teóricos e Metodológicos da Geografia (São Paulo: HUCITEC, 1996), 124.

Santos, Milton, Técnica Espaço Tempo: Globalização e Meio Técnico-Científico Informacional (São Paulo: HUCITEC, 1994), 190.

Simoni, Lucia Noemia, "A Planta da cidade de São Paulo de 1897: uma cartografia da cidade existente ou da cidade futura?" (paper presented at III Simpósio Luso-Brasileiro de Cartografia Histórica, November 10-13, 2009).

Stiel, Waldemar Correa, História dos Transportes Coletivos em São Paulo (São Paulo: McGraw-Hill do Brasil Ldta, 1978), 329.

Villaça, Flávio, Espaço Intra-Urbano no Brasil (São Paulo: Studio Nobel:FAPESP:Lincoln Institute, 2009), 373. 


\section{CARTOGRAPHIC REFERENCES}

Acervo Fundação Energia e Saneamento. Planta Geral da Cidade de São Paulo, São Paulo, 1905, $1: 6: 500$.

Boyer, Henry. Planta da Cidade de São Paulo levantada pela Companhia Cantareira e Esgotos 1881 (copy by de Domingues dos Santos), São Paulo, 1954, 1:5.000.

BRAZILIAN TRACTION LIGHT \& POWER COMPANY LTD. Map of the City of São Paulo: showing public utilities operated by subsidiary companies. São Paulo, 1924, graphic scale in miles.

BRAZILIAN TRACTION LIGHT \& POWER COMPANY LTD. Plan of the City of São Paulo and Environs. São Paulo, 1927, 1:40.000.

Bresser, Carlos Abrãao. Mappa da Cidade de São Paulo e seus Subúrbios 1847. São Paulo: 1954, $1: 5.800$

Cardim, Gomes. Planta Geral da Capital de São Paulo 1897. São Paulo, 1954, 1:20.000.

Cardoso, João Pedro. - COMISSÃO GEOGRAPHICA E GEOLOGICA. Planta Geral da Cidade de São Paulo com indicações diversas. São Paulo, 1914, 1:20.000.

Cococci, Alexandre Mariano e Costa, Luiz Fructoso. Planta Geral da Cidade de São Paulo. São Paulo: Adotada pela Prefeitura Municipal para uso de suas repartições, 1905, 1:20.000.

Lima, Cesar Bierrembach de.(org.) . Planta da Cidade de São Paulo em 1850. São Paulo, w/date, w/scale.

Martin, Jules e Albuquerque, Fernando. Mappa da Capital da Província de S.Paulo 1877. São Paulo, 1877, 1:3.500.

Martin, Jules. Planta da Capital do Estado de S. Paulo e seus arrabaldes 1890. São Paulo, 1954, $1: 6.000$.

PREFEIRURA DO MUNICÍPIO DE SÃO PAULO. Planta da cidade de S. Paulo: mostrando todos os arrabaldes e terrenos arruados. Rio de Janeiro, 1924, 1:30.000, http://smdu.prefeitura.sp.gov.br/historico_demografico/img/mapas/1924.jpg , last acess: March, 2016.

Rath, Carl (attributed). Planta da Cidade de São Paulo 1868. São Paulo, 1954, approximate scale $1: 10.000$.

Recebido em outubro de 2015.

Aceito em março de 2016. 